\section{Tropical Journal of Pathology and Microbiology}

2021 Volume 7 Number 3 May-June

\title{
Aberrant expression of E-cadherin in infiltrating ductal and lobular breast carcinomas and its correlation with clinicopathological parameters - A hospital-based study
}

\author{
Thota S. ${ }^{1}$, Chavan R. ${ }^{2}$, Jaikumar Kulkarni N. ${ }^{3 *}$ \\ DOI: https://doi.org/10.17511/jopm.2021.i03.02
}

\footnotetext{
1 Shruthi Thota, Assistant Professor, Department of Pathology, Government Medical College, Nizamabad, Kaloji Narayana Rao University of Health Sciences, Warangal, Telengana, India.

2 Ramesh Chavan, Professor, Department of Pathology, Jawaharlal Nehru Medical College, KLE University, Belagavi, Karnataka, India.

3* Naresh Jaikumar Kulkarni, Assistant Professor, Department of Pathology, Mahatma Gandhi Mission Medical College, Mahatma Gandhi Mission Institute of Health Sciences, Navi Mumbai, Maharastra, India.
}

Introduction: Breast carcinoma is one of the commonest malignant tumours in women, leading to premature deaths and morbidity. E-cadherin is a $120 \mathrm{kDa}$ calcium-dependent transmembrane glycoprotein encoded by the $\mathrm{CDH} 1$ gene located on chromosome 16q21 and is expressed in most epithelial cells. Loss of E Cadherin expression implies cell discohesion and favours metastasis. Materials and Methods: A total of 30 cases of breast carcinomas were studied, over two years. Histological grade and type were assessed by staining the paraffin-embedded sections with $\mathrm{H} \& \mathrm{E}$. Using IHC technique, E-cadherin antigen was retrieved by Heat-Induced Epitome Retrieval method, and immunostaining was scored semiquantitatively. Cases were grouped as 'preserved,' when positivity was strong membranous, and occurred in more than $75 \%$ of the neoplastic epithelial cells and 'aberrant' in all the remaining cases. Results: E-cadherin was found to be preserved in $46.7 \%$ of all the breast carcinomas and aberrant in $51.7 \%$ of invasive ductal carcinomas (IDC) alone, while $100 \%$ of invasive lobular carcinomas showed aberrant expression. No significant correlation was found with E-cadherin grading and histological type of carcinoma, histopathological grade or involvement of deep surgical margin. Conclusion: Differentiation between invasive ductal and invasive lobular carcinoma based on the loss of E-cadherin has to be done cautiously given its aberrant expression in ductal carcinomas as well.

Keywords: Invasive Ductal Carcinoma (IDC), Invasive Lobular Carcinoma (ILC), E-cadherin, IHC, Grading of E-cadherin, Aberrant E-cadherin expression, Breast carcinoma

\section{Corresponding Author}

Naresh Jaikumar Kulkarni, Assistant Professor, Department of Pathology, Mahatma Gandhi Mission Medical College, Mahatma Gandhi Mission Institute of Health Sciences, Navi Mumbai, Maharastra, India. Email: mailshruthit@gmail.com

\section{How to Cite this Article}

Thota S, Chavan R, Kulkarni NJ. Aberrant expression of E-cadherin in infiltrating ductal and lobular breast carcinomas and its correlation with clinicopathological parameters - A hospital-based study. Trop J Pathol Microbiol. 2021;7(3):99-109. Available From https://pathology.medresearch.in/index.php/jopm/ar ticle/view/540

\section{To Browse}

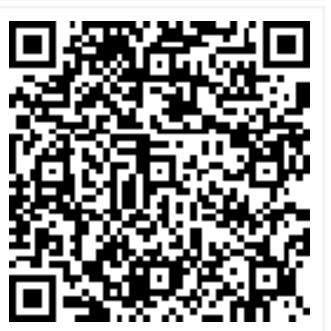

Manuscript Received 2021-06-06

Conflict of Interest No

Review Round 1
2021-06-08
Funding
Nil

$\begin{gathered}\text { Review Round } 2 \\ \text { 2021-06-12 }\end{gathered}$
Ethical Approval
Yes

Review Round 2 Yes
Review Round 3

Plagiarism X-checker $9 \%$
Accepted 2021-06-16

(c) 2021 by Shruthi Thota, Ramesh Chavan, Naresh Jaikumar Kulkarni and Published by Siddharth Health Research and Social Welfare Society. This is an Open Access article licensed under a Creative Commons Attribution 4.0 International License https://creativecommons.org/licenses/by/4.0/ unported [CC BY 4.0]. 


\section{Introduction}

Breast carcinomas are the most common of the malignant tumours and the leading cause of cancerrelated death in women with more than one lakh cases occurring worldwide annually [1]. It accounts for 25-32 percent of all cancers in women in India and 12.5 percent worldwide[2]. The important morphologic prognostic factors in invasive carcinoma of the breast include the size of the primary tumour, microscopic grade, axillary lymph node metastasis, blood and lymph vessel emboli, tumour necrosis, skin invasion and nipple invasion[3]. Other possible prognostic parameters like cell proliferation index, estrogen receptor, progesterone receptor, Her2 neu receptor status, p53, bcl-2 are of growing interest [4]. Some studies have shown an independent prognostic significance of histologic grade in breast cancer[5-7] although grading is a subjective evaluation that may have problems with reproducibility $[8,9]$.

The grading of breast cancer was first suggested in 1957 by Bloom and Richardson which was based mainly on architectural features. It was modified by Nottingham and the grade is now obtained by adding up the score for the tubule formation, nuclear pleomorphism, mitotic count.10 The Nottingham modification of the Scarff- BloomRichardson (NSBR) grading system provides a platform for uniformity in grading[10,12]. The Nottingham Prognostic Index (NPI), is calculated from three parameters namely tumour size, lymph node stage and histologic grade[13]. It predicts prognosis and helps to distinguish groups of patients suitable for different forms of therapy[13].

The mechanism of progression is not completely recognised. Research suggests that the extracellular part of cadherin, via the ions of calcium, influences catenin with similar molecules on the neighbouring cell. Thus, they create an adhesive complex that maintains cells in compact connection [14]. The cancerous process results in the reduction of the amount of cadherin, which in turn results in disorder in the transition of intracellular signals, and loosened intercellular connections. This leads to increased cells' invasiveness and ability to migrate[15]. Previous data confirm that diminished E-cadherin expression is seen in patients suffering from breast, lung, prostate and stomach cancer[16]. and this correlated with histological grading/reduced variations/of cancer, presence of distant metastasis, and worse prognosis [17].
The results estimating $\mathrm{E}$-cadherin in patients with breast cancer are contradictory. In most of them, it was proved that the loss of E-cadherin expression was a bad prognostic factor[18] and was connected with a higher level of malignancy, metastasis in axillary lymph nodes, absence of estrogen and progesterone receptors, and presence of recurrence[19]. The objective of this study is to study analyse the E-cadherin expression in both infiltrating ductal and lobular carcinomas of the breast and to determine its usefulness in distinguishing one from the other.

\section{Materials and methods}

Setting: Department of Pathology, Jawaharlal Nehru Medical College, Belagavi.

Duration and type of study: A cross- sectional study conducted for a period of two years from January 2014 to December 2015.

Sampling methods: This study was conducted on 30 patients who were histologically diagnosed as either infiltrating ductal carcinoma or infiltrating lobular carcinoma.

Sample size: 30 cases

Inclusion criteria: Histologically proven carcinoma of the breast

Exclusion criteria: Breast cancer specimens received:

- From patients who have undergone chemotherapy for breast carcinoma

- From patients with recurrent carcinoma breast

- Where there are no sufficient viable tumour cells for the accurate evaluation of the immunohistochemical results.

Sample Collection procedure: The specimens were thoroughly examined and clinical details were analysed. The specimen sent in formalin was sliced at $1 \mathrm{~cm}$ intervals and fixed immediately in $10 \% \mathrm{NBF}$ (Neutral Buffered Formalin). One dedicated block from the tumour, fixed in formalin for not more than 24 hours, was used for IHC. Four-micron thickness sections were cut and taken on amino silane coated slides and stained for evaluating E- Cadherin expression. Also, the sections were routinely stained with $\mathrm{H}$ \& $\mathrm{E}$ and histological grading of the tumour was done on these sections according to Modified Bloom- Richardson grading. 


Table-1: $\begin{aligned} & \text { Histological } \\
& \text { mottingham } \\
& \text { modification of Scarff }\end{aligned}$ Bloom
Richardson system [10].
\begin{tabular}{|l|c|l|l|}
\hline \multicolumn{1}{|c|}{ Criteria } & Score- 1 & \multicolumn{1}{c}{ Score- 2} & \multicolumn{1}{c|}{ Score- 3} \\
\hline Tubule formation & $>75 \%$ of tumour & $\begin{array}{l}10-75 \% \text { of } \\
\text { tumour }\end{array}$ & $<10 \%$ of tumour \\
\hline $\begin{array}{l}\text { Nuclear } \\
\text { pleomorphism }\end{array}$ & $\begin{array}{l}\text { Minimal variation } \\
\text { in size and shape } \\
\text { of nuclei }\end{array}$ & $\begin{array}{l}\text { Moderate } \\
\text { variation in size } \\
\text { and shape of } \\
\text { nuclei }\end{array}$ & $\begin{array}{l}\text { Marked variation } \\
\text { in size and shape } \\
\text { of nuclei }\end{array}$ \\
\hline $\begin{array}{l}\text { Mitotic count per } 10 \\
\text { hpf }(0.44 \mathrm{~mm}) \text { filled } \\
\text { diameter }\end{array}$ & $0-5$ & $6-10$ & $>11$ \\
\hline
\end{tabular}

Table-2: The scores are of the histological grading[10]

\begin{tabular}{|l|l|}
\hline \multicolumn{1}{|c|}{ Grades } & \multicolumn{1}{c|}{ Scores } \\
\hline Grade 1 & $3-5$ \\
\hline Grade 2 & 6,7 \\
\hline Grade 3 & 8,9 \\
\hline
\end{tabular}

Scoring of E-cadherin: The procedure followed for IHC staining is according to standard guidelines. IHC stained sections were observed under light microscopy and the staining was scored. E-cadherin staining interpretation has been adapted from a study done by Esposito N and David J Dabbs, published in Modern Pathology in 200724.

- The immunoreactivity with E-cadherin was scored semiquantitatively as follows:

- Strong inter-membranous staining in $>75 \%=$ $3+$; moderate staining in $26-75 \%=2+$, weak staining in $1-25 \%=1+$, absence of membranous staining $=0$ Cases were grouped as 'preserved,' when positivity was strong membranous, and occurred in more than $75 \%$ of the neoplastic epithelial cells and 'aberrant' in all the remaining cases, including the ones where staining was absent[26].

Statistical analysis: It was done using " $R$ " software and the relationship between clinicopathological parameters, IHC grading, and histopathological grading was established using Fischer exact test.

\section{Results}

In the present study, age ranged from 32 to 70 years and the mean age \pm SD was $49.7 \pm 10.29$ years. Majority, 10 cases (33.4\%) occurred in 4150 years age group followed by 9 (30\%) in 51-60 years, $7(23.3 \%)$ in $31-40$ years, and $4(13.3 \%)$ in 61-70 years age group (Table -3 ).
29 cases $(97 \%)$ were women and one case $(3 \%)$ was a 67-year-old man. 24 patients (80\%) presented with breast lump alone, followed by breast lump associated with nipple retraction in 3 patients $(10 \%)$, breast lump with nipple discharge in 2 patients $(6.7 \%)$ and only one patient $(3.3 \%)$ had breast lump associated with pain.

One case $(3.3 \%)$ had a family history of carcinoma. The size of tumor measured between $2.0-5.0 \mathrm{cms}$ in 14 cases ( $46.7 \%)$, followed by $\leq 2 \mathrm{cms}$ in 9 cases (30\%) and $>5 \mathrm{cms}$ in 7 cases $(23.3 \%)$.

Table 3: Age distribution of carcinoma breast

\begin{tabular}{|l|l|l|}
\hline \multicolumn{1}{|c|}{ Age in years } & \multicolumn{1}{c|}{ Number of patients } & \multicolumn{1}{c|}{$\%$} \\
\hline $31-40$ & 7 & 23.3 \\
\hline $41-50$ & 10 & 33.4 \\
\hline $51-60$ & 9 & 30 \\
\hline $61-70$ & 4 & 13.3 \\
\hline Total & 30 & 100 \\
\hline
\end{tabular}

Mean age $\pm S D=49.7 \pm 10.29$

Table - 4: Scores of histological grade: (Elston and Ellis modification of Scarff- BloomRichardson grading system)

\begin{tabular}{|l|l|l|l|}
\hline Score & Tubule formation & Nuclear pleomorphism & Mitotic counts \\
\hline 1 & $1(3.3 \%)$ & $0(0 \%)$ & $27(90 \%)$ \\
\hline 2 & $17(56.7 \%)$ & $12(40 \%)$ & $3(10 \%)$ \\
\hline 3 & $12(40 \%)$ & $18(60 \%)$ & $0(0 \%)$ \\
\hline Total & 30 & 30 & 30 \\
\hline
\end{tabular}

In the current study, 17 cases (56.7\%) had a score of $2,12(40 \%)$ had a score of 3 and one cases (3.3\%) had a score of 1 for tubule formation. Concerning nuclear pleomorphism, eighteen cases $(60 \%)$ had a score of $3,12(40 \%)$ has a score of 2 and none had a score of 1 .

Twenty-seven cases (90\%) had score 1, 3 (10\%) had score 2 and none had a score of 3 of mitotic count (Table -4).

Table-5: Histological grade in various types of carcinoma breast (Elston and Ellis modification of the Scarff- Bloom- Richardson grading system)annexure $\mathrm{V}$

\begin{tabular}{|l|l|l|}
\hline \multicolumn{1}{|c|}{ Histological grade } & \multicolumn{1}{c|}{ No. of patients } & \multicolumn{1}{c|}{$\%$} \\
\hline Grade 1 & 7 & 23.3 \\
\hline Grade 2 & 21 & 70 \\
\hline Grade 3 & 2 & 6.7 \\
\hline Total & 30 & 100 \\
\hline
\end{tabular}

In the present study, 21 cases (70\%) were of histological grade 2 , followed by 7 cases $(23.3 \%)$ of grade 1 and 2 cases (6.7\%) of grade 3 (Table -5 ). 
The predominant histologic subtype was infiltrating ductal carcinoma (NOS) amounting to 27 cases (90\%), followed by 2 cases $(6.7 \%)$ of intracystic papillary carcinoma and one case $(3.3 \%)$ of invasive lobular carcinoma.

\section{Table-6: Clinical and Gross features in 27} cases of IDC NOS

\begin{tabular}{|c|c|c|}
\hline & Number $(\mathrm{n}=\mathbf{2 7})$ & $\%$ \\
\hline \multicolumn{3}{|c|}{ Gender distribution } \\
\hline Female & 27 & 100 \\
\hline Male & 0 & 0 \\
\hline \multicolumn{3}{|l|}{ Gross appearance } \\
\hline Nipple retraction & 3 & 11.1 \\
\hline Peaude orange & 0 & 0 \\
\hline Ulceration & 1 & 3.7 \\
\hline \multicolumn{3}{|l|}{ Cut surface } \\
\hline Infiltrating & 26 & 96.3 \\
\hline Circumscribed & 1 & 3.7 \\
\hline Nodular & 0 & 0 \\
\hline Diffuse & 0 & 0 \\
\hline \multicolumn{3}{|l|}{ Consistency } \\
\hline Firm & 26 & 96.3 \\
\hline Gritty & 1 & 3.7 \\
\hline
\end{tabular}

Table-7: Microscopic features of 27 cases of IDC-NOS

\begin{tabular}{|l|l|l|}
\hline \multicolumn{1}{|c|}{ Histological grade } & No. of cases & \multicolumn{1}{c|}{$\%$} \\
\hline Grade 1 & 6 & 22.2 \\
\hline Grade 2 & 19 & 70.4 \\
\hline Grade 3 & \multicolumn{2}{|l|}{} \\
\hline Other features & \multicolumn{2}{|l|}{} \\
\hline DCIS component & 5 & 7.4 \\
\hline Necrosis & 9 & 18.5 \\
\hline Hemorrhage & 4 & 33.3 \\
\hline Calcification & 4 & 14.8 \\
\hline Osseous metaplasia & 0 & 0 \\
\hline Lymphocyte reaction & 1 & 3.7 \\
\hline Lymohovacular invasion & 7 & 25.9 \\
\hline Deep surgical margin involved & 9 & 33.3 \\
\hline Lymphnode status & 4 & 14.8 \\
\hline Positive & \multicolumn{2}{|l}{} \\
\hline Negative & 12 & 44.4 \\
\hline Not- available & 10 & 37 \\
\hline
\end{tabular}

Of the 27 IDC NOS specimens, 19 were of MRM, 7 were of lumpectomy, and one was of TRM. In the majority of the cases, the cut surface showed a grey-white tumour with infiltrating border and firm to hard in consistency (Table - 6). Histologically, 19 cases $(70.4 \%)$ are grade 2 tumours, followed by 6 $(22.2 \%)$ of grade 1 , and $2(7.4 \%)$ of grade 3 .
Necrosis and haemorrhage were seen in 9 (33.3\%) and 4 cases $(14.8 \%)$ respectively. Calcification was not seen in any of these cases. In one case $(3.7 \%)$, osseous metaplasia was observed. Insitu component was noticed in $5(18.5 \%)$ of cases, with comedo necrosis as the most common pattern. Four cases $(14.8 \%)$ showed involvement of deep surgical margin. Twelve out of 25 cases in which lymph nodes were available showed metastasis and the rest showed reactive changes (Table -7 ).

Out of 30 cases, 2 were IDC variant of intracystic papillary carcinoma and one was invasive lobular carcinoma, of which one intracystic papillary carcinoma was seen in a 67-year male. Both the papillary carcinomas had shown microcalcification histologically, and no involvement of the lymph nodes. Whereas, one case had shown an association with in situ component and necrosis while the other had a lymphovascular invasion. The case of invasive lobular carcinoma showed lymphocytic infiltration, Indian file pattern, targetoid pattern, lymphovascular invasion but no necrosis, haemorrhage or any association with in situ component was noted. The lymph nodes showed metastatic deposits.

Male breast carcinoma: 1 case (3.3\%)In the present study, one case of intracystic papillary carcinoma was seen in a 67-year-old male patient. The specimen was of MRM which showed a greywhite tumour with infiltrating border. Histologically, the tumour was of grade 1 and showed large round to oval cells arranged predominantly in papillary fashion, also in groups, cords and tubules at places, separated by fibrous tissue. Lymphovascular invasion was present, though the lymph nodes did not show any metastatic deposits.

Table-8: Lymph node status in various types of carcinoma breast

\begin{tabular}{|l|l|l|}
\hline \multicolumn{1}{|c|}{ Lymph node status } & \multicolumn{1}{|c|}{ No. of patients $(\mathbf{n}=30)$} & \multicolumn{1}{c|}{$\%$} \\
\hline Positive & 13 & 43.3 \\
\hline Negative & 12 & 40 \\
\hline Not available & 5 & 16.7 \\
\hline
\end{tabular}

In the current study, 13 cases (43.3\%), showed nodal metastasis, 12 (40\%) were negative for tumour deposits while in $5(16.7 \%)$ cases, nodes were not available for examination (Table - 17).

Immunohistochemical profile: In the present study, 14 cases (47\%) showed +3 , E-cadherin grade, 7 (23\%) showed $+2,8$ cases(27\%) showed +1 , and one case $(3 \%)$ showed grade 0 
Immunostaining (Table - 17) IHC scoring: The interpretation of E-cadherin immunostaining was adapted from a study done by Esposito and David Dabbs [24].

Table-9: Interpretation of E-cadherin

\begin{tabular}{|l|l|l|}
\hline \multicolumn{1}{|c|}{ Grade } & \multicolumn{1}{c|}{ No. of cases $(\mathbf{n}=\mathbf{3 0})$} & \multicolumn{1}{c|}{$\%$} \\
\hline+3 & 14 & 46.7 \\
\hline+2 & 7 & 23.3 \\
\hline+1 & 8 & 26.7 \\
\hline 0 & 1 & 3.3 \\
\hline Total & 30 & 100 \\
\hline
\end{tabular}

In the present study, 14 cases $(46.7 \%)$ showed +3 E-cadherin grade, i.e, strong intermembranous expression in $>75 \%$ of tumor cells, 7 cases $(23.3 \%)$ showed +2 , i.e, moderate staining in 26 $75 \%$ of cells, and 8 cases ( $26.7 \%$ ) showed +1 , i.e, weak membranous staining in $<25 \%$ of tumor cells. One case $(3.3 \%)$ was invasive lobular carcinoma which showed a complete absence of membrane staining (Table - 9). Grade of +3 (46.7\%) was considered as a preserved expression of E-cadherin while $+2,+1$ and 0 grades, were considered as aberrant expression of E-cadherin, which accounted for 16 cases (53.3\%).

Graph - 1: Correlation between the E-cadherin immunostain grading and the lymph node status

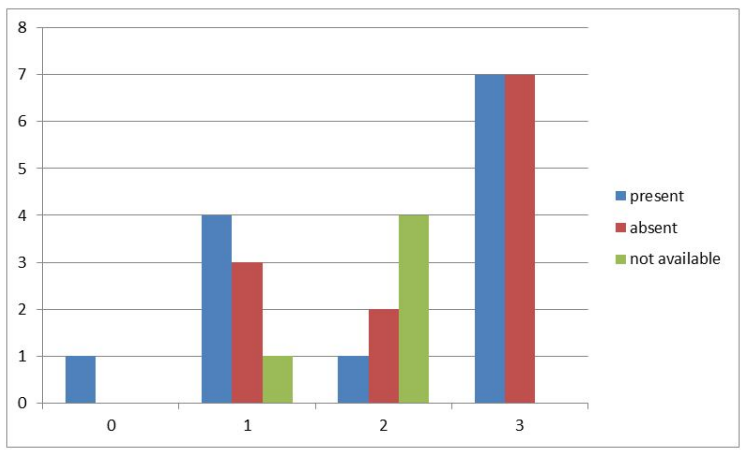

In this study, 1 (3.3\%) case showed 0 grade, 8 $(26.7 \%)$ cases showed $+1,7(23.3 \%)$ showed +2 and $14(46.7 \%)$ showed $+3 \mathrm{E}$-cadherin immunostain. The case which showed 0 grade had a positive lymph node. Of the 8 cases $(26.7 \%)$ of +1 , 4 showed lymph node positivity, of the 7 cases of +2 grade, only 1 showed positivity and of 14 cases (46.7\%) of $+3,7$ showed positive and 7 showed negative lymph nodes. In 5 cases, lymph nodes were not retrieved. The $p$-value was at 0.046 , hence not correlating with the E-cadherin loss (graph 1 ).

\section{Graph-2: Correlation between E-cadherin grading and the histopathological grade}

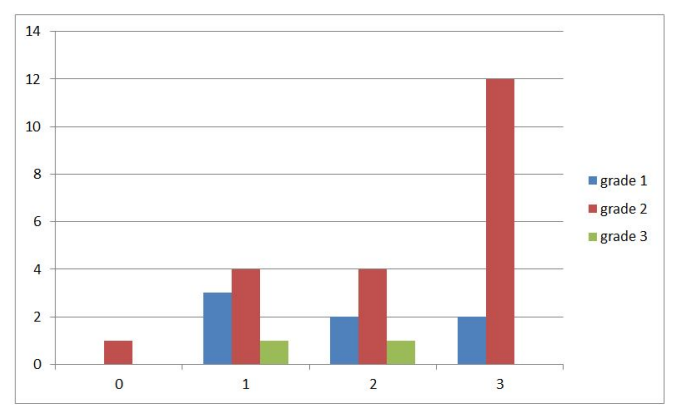

In this study, one case (3.3\%) of grade $0 \mathrm{E}$ cadherin was of histopathological grade 2 . Of the eight cases $(26.7 \%)$ of $+1,3$ were grade 1 , four were grade 2 and 1 was grade 3 . Of the 7 (23.3\%) cases of $+2 \mathrm{E}$-cadherin grade, 2 were grade 1,4 were grade 2 , and one was grade 3 . Of the 14 cases $(46.7 \%)$ of +3 immunostain, 2 were grade 1,12 were grade 2 . There was no correlation with the Ecadherin immunostaining with that of the histopathological grade as the p-value was 0.405 which is not significant. (graph 2).

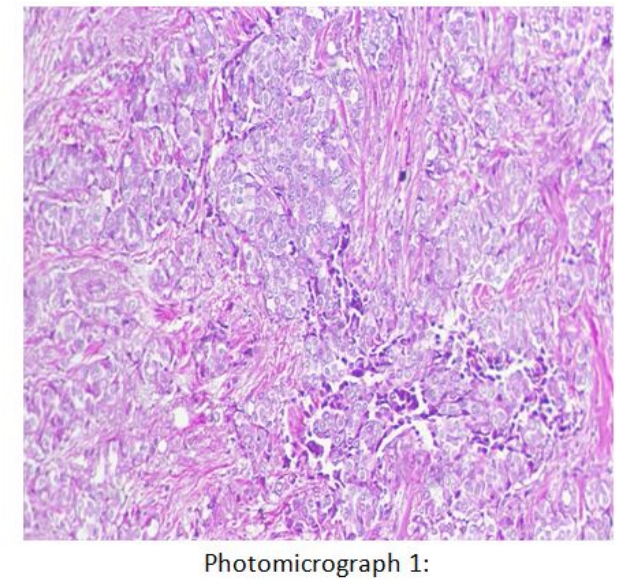

Showing invasive ductal carcinoma-Grade $3(H \& E, x 10)$

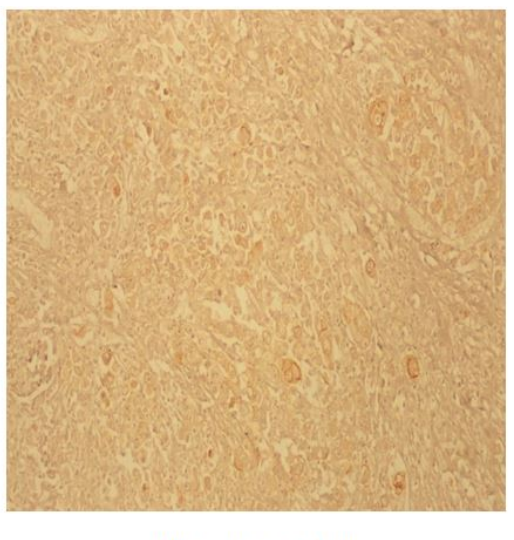

Photomicrograph 2:

Showing mild membranous staining of E-cadherin in $<25 \%$ tumour cells, in invasive ductal carcinoma E-cadherin grade $+1(\mathrm{IHC}, \times 10)$ 


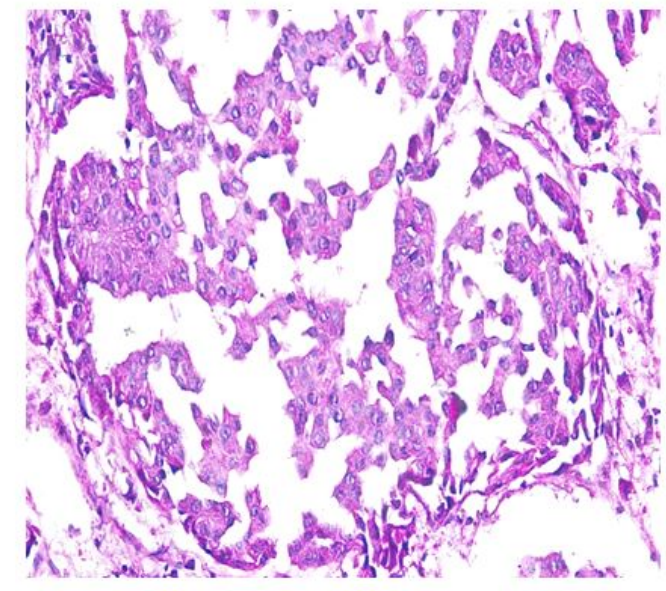

Photomicrograph 4 :

Showing invasive ductal carcinoma - Grade 2 ( $H$ \& E, x 20)

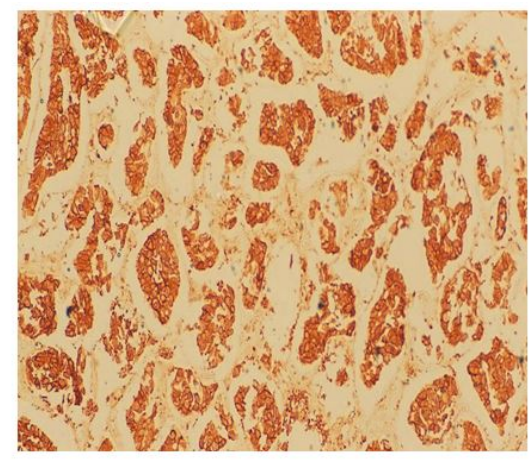

Photomicrograph 5:

Showing strong inter -membranous staining of E-cadherin in $>75 \%$ of

tumour cells, in invasive ductal carcinoma $-\mathrm{E}$-cadherin grade $+3(\mathrm{IHC}, \times 10)$

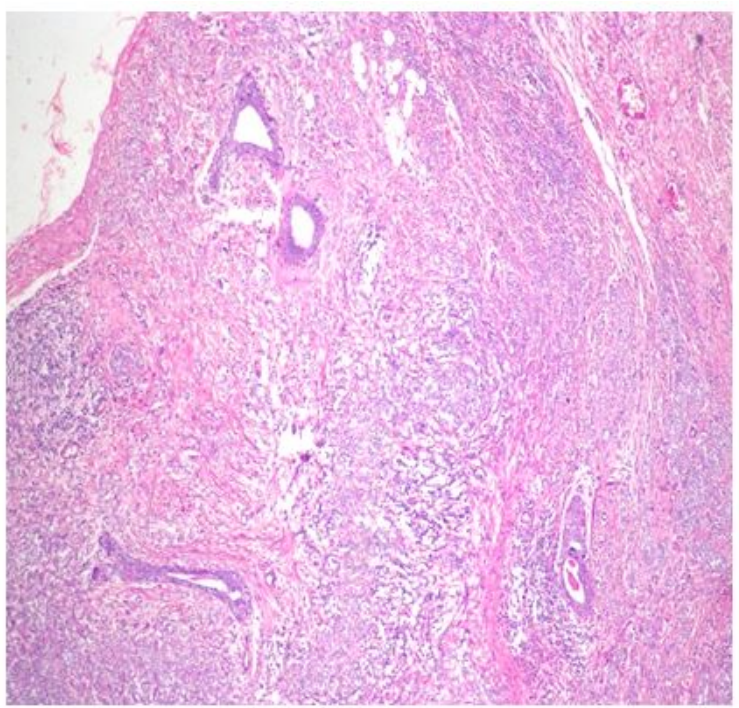

Photomicrograph 10:

Showing targetoid pattern in invasive lobular carcinoma - Grade 2 ( $\mathrm{H} \& \mathrm{E}, \mathrm{x}$ 10)

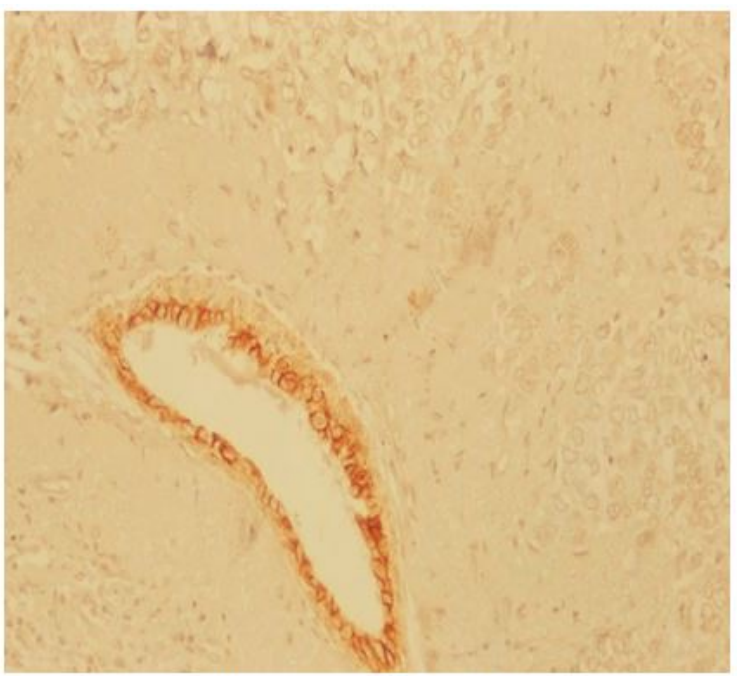

Photomicrograph 12 :

Showing absence of E-caldherin staining in invasive lobular carcinoma - E-cadherin grade - 0 (IHC, x 10)

\section{Discussion}

In the present study, mean age was in concordance with the study conducted by Munjal. K et al.27 and was lesser when compared to the other studies done by Amboise et al [28]. and Kowalski et al [26]. The mean age of Indian breast cancer patients is found to be lower when compared to the western countries with an average difference of 5 years. In the study conducted by Raina $V$ et al.[29]. 7\% of the carcinoma breast cases had a first degree relative with a history of breast cancer. In the present study, there is only one case of carcinoma breast with a family history, which accounts for $3.3 \%$.In the current study, all the 30 cases (100\%) presented with a breast lump, of which, 3 cases (10\%) presented with associated nipple retraction, 2 cases $(6.7 \%)$ with associated nipple discharge and one case $(3.3 \%)$ presented with lump associated with pain. In the study conducted by Raina $V$ et al.29, $96.5 \%$ of cases presented with a breast lump, $15.8 \%$ had pain, $9 \%$ had nipple retraction and $4.9 \%$ had nipple discharge. Pervin et al. 30observed that $100 \%$ of patients presented with a breast lump, of which $74 \%$ had pain, $20 \%$ had nipple discharge and $14 \%$ had nipple retraction. The findings of our study are more similar to that of Raina et al.[29].In the study conducted by Ambroise et al.[28]. and Azizum - Nisa et al.[31]. the left breast was more commonly involved accounting for $59.2 \%$ and $57 \%$ respectively. In the present study, an equal number of cases (15 cases, 50\%) were seen involving the right and left breast. 
In the present study, most of the tumours ranged between $2-5 \mathrm{~cm}$, which correlated with the studies done by Ayadi L et al.[35]. and Muddawa et al. [22].The second commonest size was found to be < $2 \mathrm{~cm}$ which correlated with Muddawa et al. [22]. The least number of cases showed tumour size of $>5 \mathrm{~cm}$ which correlated with Ayadi et al. [35].

27 cases (90\%) were Infiltrating ductal carcinoma (NOS) was the commonest histological type with 27 cases $(90 \%)$ correlating with the other studies like that of Zafrani et al. [21].and Satti MB et al. [36]. In the present study, 21 cases (70\%) were of histological grade 2, followed by 7 cases (23.3\%) of grade 1 and 2 cases (6.7\%) of grade 3 of the modified Scarff Bloom Richardson grading system. Similar observations were made by $P$ Querzoliet al.25.

Kowalski et al.26 had $23 \%$ of tumours of grade 3 and $20 \%$ of tumours of grade. In the current study, 13 cases (43.3\%), showed nodal metastasis, 12 (40\%) were negative for tumour deposits while in 5 $(16.7 \%)$ cases, nodes were not available for examination. Kowalski et al.[26]. found majority of lymph node status as positive (72\%) while Onitilo AA et al.[37].
Found majority of lymph nodes status as negative (61.2\%).

Table-10:Comparison of E-cadherin expression in breast carcinoma with other studies

\begin{tabular}{|l|l|l|l|}
\hline \multirow{2}{*}{$\begin{array}{c}\text { Cadherin } \\
\text { grade }\end{array}$} & \multicolumn{3}{|c|}{ Authors } \\
\cline { 2 - 4 } & $\begin{array}{l}\text { Kanithilatha Pai et al. } \\
{[23](n=28)(\%)}\end{array}$ & $\begin{array}{l}\text { P Querzoli et al.[25] } \\
(n=204)(\%)\end{array}$ & $\begin{array}{l}\text { Present study } \\
(n=30)(\%)\end{array}$ \\
\hline 0 & 0 & 45.1 & 3.3 \\
\hline+1 & 7.1 & 31.4 & 26.7 \\
\hline+2 & 7.1 & 18.1 & 23.3 \\
\hline+3 & 85.8 & 5.4 & 46.7 \\
\hline
\end{tabular}

In the current study, $46.7 \%$ of cases showed +3 grading, which does not correlate with other studies[23,25] which showed $85.8 \%$ and $5.4 \%$ of carcinoma breast cases with +3 respectively. A study that was done by Kanithilatha et al.[25] had a sample size of 28 , which is closer to our study but all of which were IDC, which probably explains why none of their cases showed grade 0 E-cadherin. But there is a huge difference in the percentage of cases showing +3 between their study and the current study and thus no correlation (Table - 10).

Table-11: Correlation of E-cadherin expression with histological grade of the tumor

\begin{tabular}{|c|c|c|c|c|c|c|}
\hline \multirow[t]{2}{*}{ Histological Grade } & \multicolumn{6}{|c|}{ Authors } \\
\hline & \multicolumn{2}{|c|}{ Sekar et al.38 (\% of E-cadherin expression) } & $p$-value & \multicolumn{2}{|c|}{ The present study (\% of E-cadherin expression) } & \multirow[t]{2}{*}{$p$-value } \\
\hline Preserved & Aberrant & 0.4 & Preserved & Aberrant & 0.27 & \\
\hline 1 & 50 & & 50 & 28.6 & & 71.4 \\
\hline 2 & 46.7 & & 53.3 & 57.1 & & 42.9 \\
\hline 3 & 16.7 & & 83.3 & 0 & & 100 \\
\hline
\end{tabular}

In our study, histological grade 3, showed $100 \%$ aberrant expression of E-cadherin which is comparable with Sekar et al. [38]. followed by histological grade 1 with $71.4 \%$ and grade 2 with
$42.9 \%$ of aberrant expression of E-cadherin. Hence E-cadherin expression of histological grade 1 and 2 does not correlate with Sekar et al.[38] (Table 11).

\section{Table-12: Correlation between histological type and E-cadherinexpression}

\begin{tabular}{|l|l|l|l|l|}
\hline $\begin{array}{c}\text { Histological } \\
\text { type }\end{array}$ & $\begin{array}{c}\text { Kanithilatha et al.[23] Preserved } \\
\text { expression (\%) }\end{array}$ & $\begin{array}{c}\text { Sauer et al.[39] Preserved } \\
\text { expression (\%) }\end{array}$ & $\begin{array}{c}\text { Kowalski et al. [26] Preserved } \\
\text { expression (\%) }\end{array}$ & $\begin{array}{c}\text { Present study Preserved } \\
\text { expression (\%) }\end{array}$ \\
\hline IDC NOS & 85.7 & 15 & 55 & 48.3 \\
\hline ILC & 0 & 0 & 0 & 0 \\
\hline
\end{tabular}

Correlation between E-cadherin expression and histological type: In our study, $48.3 \%$ of IDC NOS showed preserved expression of E-cadherin which is comparable with the study of Kowalski et al.[26] that showed 55\% preserved expression.
While Kanithilatha et al.[23] found that $85.7 \%$ of IDC NOS showed preserved expression, Sauer et al.[39] found that only $15 \%$ showed preserved expression, neither of which is correlating with our study. However, $0 \%$ of ILC in our study shows preserved E-cadherin expression, which is comparable with all other studies (Table - 12). 
Hence in our study, we found that there was no significant correlation of E-cadherin expression with the histological type ( $p=0.19$ ).In our study, we found that there was no significant correlation of the E- Cadherin expression with the size of the tumour $(p=0.4)$ as $48 \%$ of tumours with tumour size $\geq 2$ $\mathrm{cm}$ showed aberrant expression while it was preserved in 52\%. Horne et al.[40] demonstrated that, $55 \%$ of tumours with tumour size $\geq 2 \mathrm{~cm}$ showed aberrant expression vs. $45 \%$ with preserved E-cadherin expression. Sekar et al.[39]. observed, that $70 \%$ of tumours with size $\geq 2 \mathrm{~cm}$ showed aberrant expression while only $30 \%$ showed preserved expression, which is not comparable to our study.

\section{Conclusion}

Our study was an attempt to understand the Ecadherin expression, its ability to distinguish between infiltrating ductal and lobular breast carcinomas, and its correlation with clinicopathological parameters. No correlation has been found with E-cadherin expression and histological type of carcinoma, or histopathological grade, necrosis, calcification, lymphovascular invasion and lymph node status. In contrary to the previous studies[24] which established that aberrant E-cadherin expression skews the diagnosis towards invasive lobular carcinoma rather than invasive ductal carcinoma of the breast, our study revealed $51.7 \%$ of IDC cases with aberrant expression poses a question as to how reliable a marker, E-cadherin is, in differentiating ductal and lobular invasive carcinomas in breast, hence it may not have significance in routine use.

\section{What does this study add to existing knowledge?}

Differentiation between infiltrating lobular and ductal carcinomas cannot be made by using $\mathrm{E}$ Cadherin alone. There is a necessity to use newer markers to make this distinction. Recent research has shown the switch of $\mathrm{E}$-cadherin to $\mathrm{N}$-cadherin expression in invasive ductal carcinomas. Further studies on these emerging markers have to be done as there is a potential for newer cancer therapies.

\section{Authors Contribution}

Dr. Shruthi Thota: Data collection, data compiling, literature review, manuscript preparation, manuscript editing, final approval.
Dr. Naresh Jaikumar Kulkarni: Data collection, manuscript editing

Dr. Ramesh Chavan: Literature review, data compiling

\section{Reference}

01. Rosai J. Breast In- Rosai and Ackerman's surgical pathology, 9th ed. Philadelphia- Churchill Livingston. 2004;1787. [Crossref][PubMed][Google Scholar]

02. Raj P. Review of cancer statistics in India. International Journal of Advances in Signal and Image Sciences. 2015 Jan 29;1(1)1-4. [Crossref] [PubMed][Google Scholar]

03. Ahmad Z, Khurshid A, Qureshi A, Idress R, Asghar N, Kayani N. Breast carcinoma grading, estimation of tumor size, axillary lymph node status, staging, and nottingham prognostic index scoring on mastectomy specimens. Indian J PatholMicrobiol. 2009 Oct-Dec;52(4)477-81. doi: 10.4103/0377-4929.56123 [Crossref][PubMed] [Google Scholar]

04. Lari SA, Kuerer HM. Biological Markers in DCIS and Risk of Breast Recurrence- A Systematic Review. J Cancer. 2011 May 1;2;232-61. doi: 10.7150/jca.2.232 [Crossref][PubMed][Google Scholar]

05. Symmers W C. "Assessment of histological grade". Edinburgh, United Kingdom, Churchill Livingstone. 1998. [Crossref][PubMed][Google Scholar]

06. Pereira $H$, Pinder SE, Sibbering DM, Galea MH, Elston CW, Blamey RW, et al. Pathological prognostic factors in breast cancer, IV- Should you be a typer or a grader?- A comparative study of two histological prognostic features in operable breast carcinoma. Histopathology. 1995 Sep;27(3)219-26. doi: 10.1111/j.1365-2559.1995.tb00213.x [Crossref][PubMed][Google Scholar]

07. Sundquist $M$, Thorstenson $S$, Brudin $L$, Nordenskjöld B. Applying the Nottingham Prognostic Index to a Swedish breast cancer population- South East Swedish Breast Cancer Study Group. Breast Cancer Res Treat. 1999 Jan;53(1)1-8. doi: 10.1023/a:1006052115874 [Crossref][PubMed] [Google Scholar] 
08. Ugnat AM, Xie L, Morriss J, Semenciw R, Mao Y. Survival of women with breast cancer in Ottawa, Canada- variation with age, stage, histology, grade and treatment. $\mathrm{Br} \mathrm{J}$ Cancer. 2004 Mar 22;90(6)1138-43. doi: 10.1038/sj.bjc.6601662 [Crossref][PubMed][Google Scholar]

09. Dalton LW, Page DL, Dupont WD. Histologic grading of breast carcinoma- A reproducibility study. Cancer. 1994 Jun $1 ; 73(11) 2765-70$. doi:10.1002/1097-

0142(19940601)73:11<2765: :aid-

cncr2820731119>3.0.co;2-k [Crossref][PubMed] [Google Scholar]

10. Bloom $\mathrm{Hj}$, Richardson Ww. Histological grading and prognosis in breast cancer- a study of 1409 cases of which 359 have been followed for 15 years. $\mathrm{Br} J$ Cancer. 1957 Sep;11(3)359-77. doi: 10.1038/bjc.1957.43 [Crossref][PubMed][Google Scholar]

11. Elston CW, Ellis IO. Pathological prognostic factors in breast cancer, I, The value of histological grade in breast cancer: experience from a large study with long-term follow-up. Histopathology. 1991 Nov;19(5)403-10. doi: 10.1111/j.13652559.1991.tb00229.x [Crossref][PubMed][Google Scholar]

12. Genestie C, Zafrani B, Asselain B, Fourquet A, Rozan S, Validire $P$, et al. Comparison of the prognostic value of Scarff-Bloom-Richardson and Nottingham histological grades in a series of 825 cases of breast cancer- major importance of the mitotic count as a component of both grading systems. Anticancer Res. 1998 Jan-Feb;18(1B)5716. [Crossref][PubMed][Google Scholar]

13. Ellis IO, Pinder SE, Lee AHS. Tumours of the breast, In- Fletcher CDM, editor, Diagnostic histopathology of tumours. 3rd ed, PhiladelphiaChurchill Livingston. 2007;903-60. [Crossref] [PubMed][Google Scholar]

14. Takeichi M. Cadherin cell adhesion receptors as a morphogenetic regulator. Science. 1991 Mar 22;251(5000)1451-5. doi:

10.1126/science. 2006419 [Crossref][PubMed]

[Google Scholar]

15. Okegawa T, Pong RC, Li Y, Hsieh JT. The role of cell adhesion molecule in cancer progression and its application in cancer therapy. Acta Biochim Pol. 2004;51(2)445-57. Scholar]
16. Umbas $R$, Isaacs $W B$, Bringuier $P P$, Schaafsma HE, Karthaus HF, Oosterhof GO, Debruyne FM, Schalken JA. Decreased E-cadherin expression is associated with poor prognosis in patients with prostate cancer. Cancer Res. 1994 Jul 15;54(14)3929-33. [Crossref][PubMed][Google Scholar]

17. Batistatou A, Peschos D, Tsanou $H$, Charalabopoulos A, Nakanishi Y, Hirohashi S, et al. In breast carcinoma dysadherin expression is correlated with invasiveness but not with Ecadherin. $\mathrm{Br}$ J Cancer. 2007 May 7;96(9)1404-8. doi: 10.1038/sj.bjc.6603743 [Crossref][PubMed] [Google Scholar]

18. Charpin C, Garcia S, Bonnier P, Martini F, Andrac $L$, Choux $R$, et al. Reduced E-cadherin immunohistochemical expression in node-negative breast carcinomas correlates with 10-year survival. Am J Clin Pathol. 1998 Apr;109(4)431-8. doi: 10.1093/ajcp/109.4.431 [Crossref][PubMed][Google Scholar]

19. De Leeuw WJ, Berx G, Vos CB, Peterse JL, Van de Vijver $M J$, Litvinov $S$, et al. Cleton-Jansen $A M$, Simultaneous loss of E-cadherin and catenins in invasive lobular breast cancer and lobular carcinoma in situ. J Pathol. 1997 Dec;183(4)404-11. doi: 10.1002/(SICI)1096-

9896(199712)183:4<404::AID-

PATH1148>3.0.CO;2-9 [Crossref][PubMed][Google Scholar]

20. Female Reproductive System. In- Young B, Lowe JS, Stevens A, Heath JW, editors, Wheater's functional histology, A text and colour atlas. 5th ed, Churchill Livingstone, Elseveir. 2009;359-391. [Crossref][PubMed][Google Scholar]

21. Zafrani B, Aubriot $M H$, Mouret $E$, De Crémoux $P$, De Rycke $Y$, Nicolas $A$, et al. High sensitivity and specificity of immunohistochemistry for the detection of hormone receptors in breast carcinomacomparison with biochemical determination in a prospective study of 793 cases. Histopathology. 2000 Dec;37(6)536-45. doi: 10.1046/j.13652559.2000.01006.x [Crossref][PubMed][Google Scholar]

22. Siitonen SM, Kononen JT, Helin HJ, Rantala IS, Holli KA, Isola JJ. Reduced E-cadherin expression is associated with invasiveness and unfavorable prognosis in breast cancer. Am J Clin Pathol. 1996 Apr;105(4)394-402. doi: 10.1093/ajcp/105.4.394 [Crossref][PubMed][Google Scholar] 
23. Pai $K$, Baliga $P$, Shrestha BL. E-cadherin expression- a diagnostic utility for differentiating breast carcinomas with ductal and lobular morphologies. J Clin Diagn Res. 2013 May;7(5)8404. doi: 10.7860/JCDR/2013/5755.2954 [Crossref] [PubMed][Google Scholar]

24. Esposito NN, Chivukula M, Dabbs DJ. The ductal phenotypic expression of the E-cadherin/catenin complex in tubulolobular carcinoma of the breastan immunohistochemical and clinicopathologic study. Mod Pathol. 2007 Jan;20(1)130-8. doi: 10.1038/modpathol.3800721 [Crossref][PubMed] [Google Scholar]

25. Friedl $P$, Hegerfeldt $Y$, Tusch $M$. Collective cell migration in morphogenesis and cancer. Int $\mathrm{J}$ Dev Biol. 2004;48(5-6)441-9. doi: 10.1387/ijdb.041821pf [Crossref][PubMed][Google Scholar]

26. Kowalski PJ, Rubin MA, Kleer CG. E-cadherin expression in primary carcinomas of the breast and its distant metastases. Breast Cancer Res. 2003;5(6)R217-22. doi: 10.1186/bcr651 [Crossref] [PubMed][Google Scholar]

27. Munjal K, Ambaye A, Evans MF, Mitchell J, Nandedkar $S$, Cooper $K$. Immunohistochemical analysis of ER, PR, Her2 and CK5/6 in infiltrative breast carcinomas in Indian patients. Asian Pac J Cancer Prev. 2009;10(5)773-8. [Crossref][PubMed] [Google Scholar]

28. Ambroise M, Ghosh M, Mallikarjuna VS, Kurian A. Immunohistochemical profile of breast cancer patients at a tertiary care hospital in South India. Asian Pac J Cancer Prev. 2011;12(3)625-9. [Crossref][PubMed][Google Scholar]

29. Raina V, Bhutani M, Bedi R, Sharma A, Deo SV, Shukla NK, et al. Clinical features and prognostic factors of early breast cancer at a major cancer center in North India. Indian J Cancer. 2005 JanMar;42(1)40-5. doi: 10.4103/0019-509x.15099 [Crossref][PubMed][Google Scholar]

30. Pervin, Mosammat Mira, et al. "Study on Clinical Presentation of Breast Carcinoma of 50 Cases". Chattagram Maa-O-Shishu Hospital Medical College Journal. 2014;13(2)8-11. [Crossref][PubMed] [Google Scholar]
31. Azizun-Nisa, Bhurgri $Y$, Raza F, Kayani N. Comparison of ER, PR and HER-2/neu (C-erb B 2) reactivity pattern with histologic grade, tumor size and lymph node status in breast cancer. Asian Pac J Cancer Prev. 2008 Oct-Dec;9(4)553-6. [Crossref] [PubMed][Google Scholar]

32. Meena SP, Hemrajani DK, Joshi N. A comparative and evaluative study of cytological and histological grading system profile in malignant neoplasm of breast--an important prognostic factor. Indian J Pathol Microbiol. 2006 Apr;49(2)199-202. [Crossref][PubMed][Google Scholar]

33. Costa MJ, Tadros T, Hilton G, Birdsong G. Breast fine needle aspiration cytology, Utility as a screening tool for clinically palpable lesions. Acta Cytol. 1993 Jul-Aug;37(4)461-71. [Crossref][PubMed][Google Scholar]

34. Joshi K, Mehtani VG, Mehrotra GC. The pathologic profile of invasive breast cancer I, Factors intrinsic to the tumour. Indian J Cancer. 1983 Jan-Feb;20(1)15-22. [Crossref][PubMed] [Google Scholar]

35. Ayadi L, Khabir A, Amouri H, Karray S, Dammak $A$, Guermazi $M$, et al. Correlation of HER-2 overexpression with clinico-pathological parameters in Tunisian breast carcinoma. World J Surg Oncol. 2008 Oct $22 ; 6 ; 112$. doi: 10.1186/1477-7819-6-112 [Crossref][PubMed][Google Scholar]

36. Satti MB. Oestrogen receptor/progesterone receptor and human epidermal growth factor receptor 2 status in breast cancer- a 9-year study at Princess Noorah Oncology Center, Saudi Arabia. Histopathology. 2011 Sep;59(3)537-42. doi: 10.1111/j.1365-2559.2011.03883.x [Crossref] [PubMed][Google Scholar]

37. Onitilo AA, Engel JM, Greenlee RT, Mukesh BN. Breast cancer subtypes based on ER/PR and Her2 expression- comparison of clinicopathologic features and survival. Clin Med Res. 2009 Jun;7(1-2)4-13. doi: 10.3121/cmr.2009.825 [Crossref][PubMed] [Google Scholar]

38. Sekar P, Bharti JN, Nigam JS, Sharma A, Soni PB. Evaluation of p53, HoxD10, and E-Cadherin Status in Breast Cancer and Correlation with Histological Grade and Other Prognostic Factors. J Oncol. 2014;702527. doi: 10.1155/2014/702527 [Crossref][PubMed][Google Scholar] 
39. Sauer T, Boudjema G, Jebsen PW, Naess O. Immunocytochemical expression of E-cadheri on fine-needle aspirates from breast carcinomas correlate with the cell dissociation pattern seen on smears. Diagn Cytopathol. 2001 Dec;25(6)382-8. doi: 10.1002/dc.10030 [Crossref][PubMed][Google Scholar]
40. Horne HN, Sherman ME, Garcia-Closas M, Pharoah PD, Blows FM, Yang XR, et al. Breast cancer susceptibility risk associations and heterogeneity by E-cadherin tumor tissue expression. Breast Cancer Res Treat. 2014 Jan;143(1)81-7. doi: 10.1007/s10549-013-2771-z [Crossref][PubMed] [Google Scholar] 